\title{
Molecular Dynamics Simulation of Layerd Double Hydroxide (LDH) Mineral: Hydrotalcite and Water Systems
}

\author{
Katsuyuki KAWAMURA ${ }^{\text {a }}$ \\ ${ }^{a}$ Graduate School of Envirmental and Life Science, Okayama University, Okayama 700-8530, Japan \\ e-mail:kats@okayama-u.ac.jp
}

(Received: April 17, 2015; Accepted for publication: September 17, 2015; Online publication: November 26, 2015)

Some clay minerals are used and expected as barrier materials for engineering and in nature. Hydrotalcite, $\mathrm{Mg}_{6} \mathrm{Al}_{2}\left[(\mathrm{OH})_{16} \mid \mathrm{CO}_{3}\right] 4 \mathrm{H}_{2} \mathrm{O}$ and a kind of $\mathrm{LDH}$ (layered double hydroxides), is one of the most effective candidates for the anion adsorbents and the barrier. In this study, the behavior of hydrotalcite was investigated by means of the molecular dynamics method. $\mathrm{Cl}^{-}$and I-hydrotalcite - water systems were simulated for various mineral/water ratios. The structure and dynamic properties are predicted. Water at the surface of hydrotalcite shows the electric double layer composed of Stern layer of one $\mathrm{H}_{2} \mathrm{O}$ molecular layer thickness and large self-diffusion coefficient of $\mathrm{H}_{2} \mathrm{O}$ and diffusion layer of $2.5 \mathrm{~nm}$ thickness at the interface.

Keyword: Clay mineral, Molecular dynamics simulation, Physical property, Structure, Mineral-water, Interface

\section{Introduction}

Some clay minerals have been used and are expected to be used as barrier materials against cations, anions, water and aqueous solutions, gasses, etc. for engineering systems and in nature. Smectite is one of the most effective materials as cation adsorbents, water sealing, etc. in the potential engineering barriers for industrial and radioactive waste disposals, etc. On the other hand, anion mobility seems to be fairly large and the absorbability of anions is poor in smectite clays. Hydrotalcite, $\mathrm{Mg}_{6} \mathrm{Al}_{2}\left[(\mathrm{OH})_{16} \mid \mathrm{CO}_{3}\right] 4 \mathrm{H}_{2} \mathrm{O}$, is one of the most effective candidates for the anion barriers.

Hydrotalcite is a mineral relating to simple hydroxide minerals, brucite $\left(\mathrm{Mg}(\mathrm{OH})_{2}\right)$ and gibbsite $\left(\mathrm{Al}(\mathrm{OH})_{3}\right)$ having a sheet structure composed of edge-sharing octahedra. Hydrotalcite and related minerals with only octahedral cations of $\mathrm{Mg}^{2+}$ and/ or $\mathrm{Al}^{3+}$ are listed in Table 1 according to Struntz Mineralogical Tables [1]. The octahedral sites are occupied mainly by $\mathrm{Mg}^{2+}$ ions and some by $\mathrm{Al}^{3+}$ ions, and the substitution of divalent cations by trivalent cations causes the positive layer charges. Because of the solid solution of $\mathrm{Al}^{3+}$ and $\mathrm{Mg}^{2+}$ ions in the octahedral sites, and uncertainty of cation distribution in the octa- hedral sites, and of species of anions or anionic molecules and their amounts, and of amount of $\mathrm{H}_{2} \mathrm{O}$ molecules in the interlayer region; the crystal chemistry is not known completely yet.

Molecular dynamics simulations (MD) of halide bearing hydrotalcite have been carried out by some researchers. Wang et al. [2] reported the MD simulations of hydrotalcite with interlayer $\mathrm{Cl}^{-}$and $\mathrm{H}_{2} \mathrm{O}$ using CVFF_aug force field and SPC model. The water contents were 0 to 7 of $\mathrm{H}_{2} \mathrm{O} / \mathrm{Cl}$. The swelling behavior as c-axis expansion and the hydration energy and $\mathrm{H}_{2} \mathrm{O}$ potential energy were derived. Their simulations showed the stability of the hydration state at $\mathrm{H}_{2} \mathrm{O} / \mathrm{Cl}$ ratio of two. Wang et al. [3] simulated hydrotalcite, $\left[\mathrm{Mg}_{3} \mathrm{Al}(\mathrm{OH})_{3}\right] \mathrm{Cl} .3 \mathrm{H}_{2} \mathrm{O}$, to obtaine the power spectra using molecular dynamics methods with their modified CRAYFF force field and flexible SPC model. They calculated the power spectra of 0 to $600 \mathrm{~cm}^{-1}$ to compare with experimental far-infrared spectra, and found good agreement between them. They mentioned the motion of $\mathrm{Cl}^{-}$ion in the interlayer region as remarkably similar to those of bulk aqueous chloride solutions.

In this paper, the preparations of initial structures of hydrotalcite for molecular dynamics (MD) simulations of hydrotalcite 
Table 1. Hydrotalcite and related minerals. ([1] Strunts Mineralogical Tables, 2001)

\begin{tabular}{|c|c|c|c|c|c|c|c|}
\hline Mineral & \multicolumn{2}{|c|}{ Chemical formula } & System & S.G. & $\left(\mathbf{a}, \mathbf{b}, \mathbf{c}(\right.$ Angstrom $\left.), \beta\left({ }^{\circ}\right)\right)$ & \multicolumn{2}{|l|}{$\mathbf{Z}$} \\
\hline Brucite & \multicolumn{2}{|c|}{$\mathrm{Mg}(\mathrm{OH})_{2}$} & Trigonal & P-3m1 & $(3.153 .154 .77)$ & \multicolumn{2}{|l|}{1} \\
\hline Gibbsite & \multicolumn{2}{|l|}{$\gamma-\mathrm{Al}(\mathrm{OH})_{3}$} & Monoclinic & $\mathrm{P} 21 / \mathrm{n}$ & (8.66 5.07 9.72 94.5) & \multicolumn{2}{|l|}{8} \\
\hline Bayerite & \multicolumn{2}{|l|}{$\alpha-\mathrm{Al}(\mathrm{OH})_{3}$} & Monoclinic & $\mathrm{P} 21 / \mathrm{n}$ & (5.05 8.679 .4290 .3$)$ & \multicolumn{2}{|l|}{8} \\
\hline Meixnerite & \multicolumn{2}{|c|}{$\mathrm{Mg}_{6} \mathrm{Al}_{2}(\mathrm{OH})_{18} \cdot 4 \mathrm{H}_{2} \mathrm{O}$} & Trigonal & $\mathrm{R}-3 \mathrm{~m}$ & (3.05 3.0522 .93$)$ & \multicolumn{2}{|l|}{$3 / 8$} \\
\hline Hydrotalcite & \multicolumn{2}{|c|}{$\mathrm{Mg}_{6} \mathrm{Al}_{2}\left[(\mathrm{OH})_{16} \mid \mathrm{CO}_{3}\right] 4 \mathrm{H}_{2} \mathrm{O}$} & Trigonal & $\mathrm{R}-3 \mathrm{~m}$ & $(3.053 .0522 .81)$ & \multicolumn{2}{|l|}{$3 / 8$} \\
\hline Manasseite & \multicolumn{2}{|c|}{$\mathrm{Mg}_{6} \mathrm{Al}_{2}\left[(\mathrm{OH})_{16} \mid \mathrm{CO}_{3}\right] 4 \mathrm{H}_{2} \mathrm{O}$} & Hexagonal & $\mathrm{P} 63 / \mathrm{mmc}$ & $6.126 .1215 .34) 1$ & & \\
\hline Quintinite-2H & \multicolumn{2}{|c|}{$\mathrm{Mg}_{4} \mathrm{Al}_{2}\left[(\mathrm{OH})_{12} \mid \mathrm{CO}_{3}\right] 3 \mathrm{H}_{2} \mathrm{O}$} & Hexagonal & P6322 & (10.57 10.57 15.14) & \multicolumn{2}{|l|}{4} \\
\hline Quintinite-3T & \multicolumn{2}{|c|}{$\mathrm{Mg}_{4} \mathrm{Al}_{2}\left[(\mathrm{OH})_{12} \mid \mathrm{CO}_{3}\right] 3 \mathrm{H}_{2} \mathrm{O}$} & Trigonal & $\mathrm{P} 3112$ & $\left(\begin{array}{llll}10.80 & 10.80 & 22.71\end{array}\right)$ & 6 & \\
\hline \multicolumn{8}{|c|}{ MD calculation results at $298.15 \mathrm{~K}, 0.1 \mathrm{MPa}$} \\
\hline & \multicolumn{2}{|c|}{ ts at $298.15 \mathrm{~K}, 0.1 \mathrm{MPa}$} & & \multicolumn{2}{|c|}{ alpha ${ }^{\circ}$} & \multicolumn{2}{|c|}{ gamma/ } \\
\hline Brucite & 2.99836 & $5.18323(2.99254)$ & & & & & \\
\hline Gibbsite & 8.82789 & 5.11201 & & & 98.5055 & & 89.9978 \\
\hline Hydrotalcite & 3.06379 & $5.27381(3.04484)$ & & & & & \\
\hline
\end{tabular}

related systems were developed. The structure and properties of hydrotalcite with some different anions, mainly $\mathrm{Cl}^{-}$and $\mathrm{I}^{-}$, and water in the vicinity of the surface were investigated by means of MD method.

\section{Molecular dynamics simulations and interatomic potential model}

The Ewald method was used for the summations of Coulomb interactions. The cut off distance of summations of long and middle range interactions was set at the smaller one of $1.5 \mathrm{~nm}$ or the inscribed sphere radius of the periodic basic cell. The short range interactions were summed within the radius of $0.75 \mathrm{~nm}$. Integration of equation of atom motions was performed by the velocity Verlet algorithm with a time increment of $0.4 \mathrm{fs}$ because of hydrogen atoms. The NVT (in some of the cases of including vacuum space in the systems) and NPT ensembles were employed, where $\mathrm{N}$ is the number of atoms in the simulation (basic) cell, $\mathrm{V}$ the basic cell volume, $\mathrm{T}$ temperature, and $\mathrm{P}$ pressure. Pressure and temperature with the number of atoms were kept constant during the simulations with NPT emsembles. Temperature and pressure were controlled by scaling of atom velocities and basic cell edges and the shape. Molecular dynamics (MD) simulations were carried out at $293 \mathrm{~K}$ and $0.1 \mathrm{MPa}$. The MD simulation codes, MXDORTO and MXDTRICL [4] were used. At least, a 100,000 steps calculation was performed for the initial relaxation for each system. Subsequent 100,000 to $2,000,000$ steps simulations for each system were carried out to obtain ensemble averaged properties.
Before the MD calculations of surface-water drop systems, wide areas of hydrotalcite surfaces were prepared, and water drops in vacuum were prepared separately and equilibrated for $3000 \mathrm{H}_{2} \mathrm{O}$ molecule systems. MD calculations were started from the system containing the sheet of clay mineral and a water drop. The clay surface-external water systems were also simulated to obtain the interface properties.

The interatomic potential model used in this study is the pair atom central force model with full freedom of atom motions which was described by Kumagai et al. [5], Nakano et al. [6], and Kawamura [7]. The three body force term was added for $\mathrm{H}_{2} \mathrm{O}$ molecule. The two body terms represent Coulomb, van der Waarls, non-bonding short-range repulsive, and radial covalent terms (three terms) in the sequence of the following formula:

$$
\begin{aligned}
& u_{i j}\left(r_{i j}\right)=\frac{z_{i} z_{j} e^{2}}{4 \pi \varepsilon_{0} r_{i j}} \\
& \quad-\frac{c_{i} c_{j}}{r_{i j}^{6}} \\
& \quad+f_{0}\left(b_{i}+b_{j}\right) \exp \left(\frac{a_{i}+a_{j}-r_{i j}}{b_{i}+b_{j}}\right) \\
& \quad+D_{l i j} \exp \left(-\beta_{1 i j} r_{i j}\right)+D_{2 i j} \exp \left(-\beta_{2 i j} r_{i j}\right)+D_{3 i j} \exp \left[-\beta_{3 i j}\left(r_{i j}-r_{3 i j}\right)^{2}\right]
\end{aligned}
$$


The three body term represents the angular part of covalent interaction;

$$
\begin{gathered}
u_{j i j}\left(\theta_{j i j}, r_{i j}\right)=-f_{k}\left\{\cos \left[2\left(\theta_{j i j}-\theta_{0}\right)\right]-1\right\} \sqrt{k_{1} k_{2}} \\
k_{1}=\frac{1}{\exp \left[g_{r}\left(r_{i j 1}-r_{m}\right)\right]+1}
\end{gathered}
$$

The parameters appearing in this formula, z, c, a, and b, for atoms, $D_{1}, D_{2}, D_{3}, \beta_{1}, \beta_{2}, \beta_{3}$, and $r_{3}$ for atom pairs, $f_{k}, \theta_{0}, g_{r}$, and $r_{m}$ for three atoms, were presented for the molecular simulations of systems relating to $\mathrm{H}_{2} \mathrm{O}, \mathrm{CO}_{3}{ }^{2-}$, clay minerals, and related crystalline materials (Table 2 ).

Using therse parameters, the lattice parameters and crystal structures of brucite, gibbsite, and hydrotalcite were reasonably reproduced as shown in Table 1 .

\section{Crystal structure of hydrotalcite}

Although with the rather simple chemical formula of hydrotalcite, $\mathrm{Mg}_{6} \mathrm{Al}_{2}\left[(\mathrm{OH})_{16} \mid \mathrm{CO}_{3}\right] 4 \mathrm{H}_{2} \mathrm{O}$, the relation between the crystal structure and the chemistry shows complex features. The crystal data of hydrotalcite by Allmann and Jepsen [8] and by Bellotto et al. [9] are shown in Table 3. The chemical formulas of these two reports are different from each other. Both of the crystal structure data have site occupancy factors (SOF) for $\mathrm{Al}, \mathrm{Mg}, \mathrm{CO}_{3}{ }^{2-}$, and $\mathrm{H}_{2} \mathrm{O}$, and there is no description of their distributions. These structure data cannot be used for MD calculations as they stand, because the "true" atom positions in the

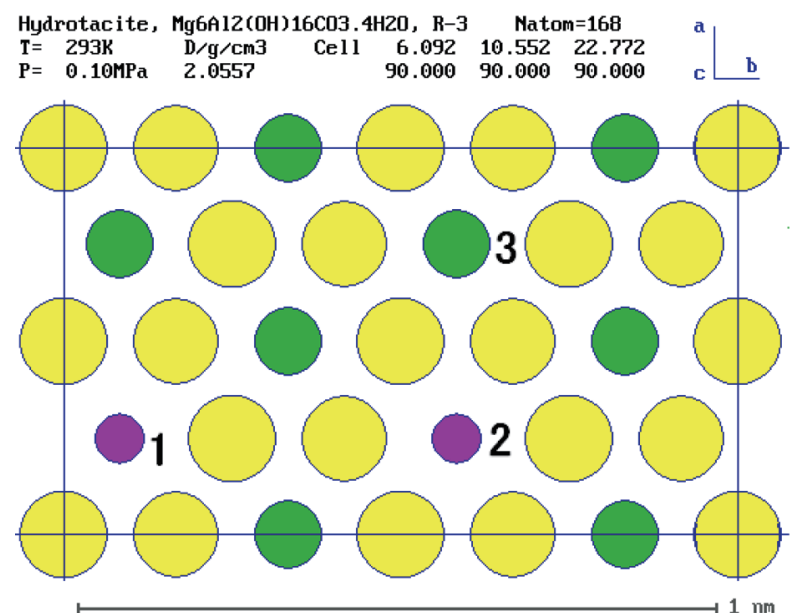

Figure 1. Unit structure of hydrotalcite as octahedral sheet. Large, middle and small circles are $\mathrm{O}, \mathrm{Mg}$, and $\mathrm{Al}$ atoms, middle $\mathrm{Mg}$ atoms respectively. unit cell should be given properly to perform MD simulation.

When $\mathrm{Mg}: \mathrm{Al}=3: 1$, the octahedral sheet may have ordered structure. Figure 1 in which the a-edge length was doubled, and the b-edge length was changed because of converting from the trigonal cell into orthorhombic cell, shows one of the ordered models ( $\mathrm{Al}$ atoms at sites 1 and 2), and another model is that of $\mathrm{Al}$ atoms at sites 1 and 3 under the condition that $\mathrm{Al}$ atoms do not adjoin each other. When $\mathrm{Mg}: \mathrm{Al}=2: 1$, the structure should include adjoining of $\mathrm{Al}$ octahedra.

In our model, the unit cell ( $\mathrm{R}-3, \mathrm{Z}=3$ for $\mathrm{Mg}_{6} \mathrm{Al}_{2}\left[(\mathrm{OH})_{16} \mid \mathrm{CO}_{3}\right]$ $\left.4 \mathrm{H}_{2} \mathrm{O}\right)[8],(\mathrm{a}, \mathrm{b}, \mathrm{c})=0.61 \mathrm{~nm} \times 1.06 \mathrm{~nm} \times 2.28 \mathrm{~nm}$ was multiplied by $(4,2,1)$ as the MD basic cell. We calculated for three types of hydrotalcite, $\mathrm{CO}_{3}{ }^{2-}, \mathrm{Cl}^{-}$, and I-hydrotalcites.

The (NPT)-MD calculations of model $\mathrm{CO}_{3}{ }^{2-}$-hydrotalcite at $293 \mathrm{~K}$ and $0.1 \mathrm{MPa}$, show the average unit cell parameters of $\mathrm{a}=3.069, \mathrm{~b}=3.042$, and $\mathrm{c}=23.218 \AA$ (Angstrom) giving the density of $2.00362 \times 10^{3} \mathrm{~kg} / \mathrm{m}^{3}$ which is well reproducing the reference parameters. The structure snapshot is shown in Figure 2. The octahedral sheet structure (3 layers parallel to the a-b plane) is stably maintained, and interlayer sheet also formed with $\mathrm{CO}_{3}{ }^{2-}$ and $\mathrm{H}_{2} \mathrm{O}$ molecules. The single sheet of interlayer

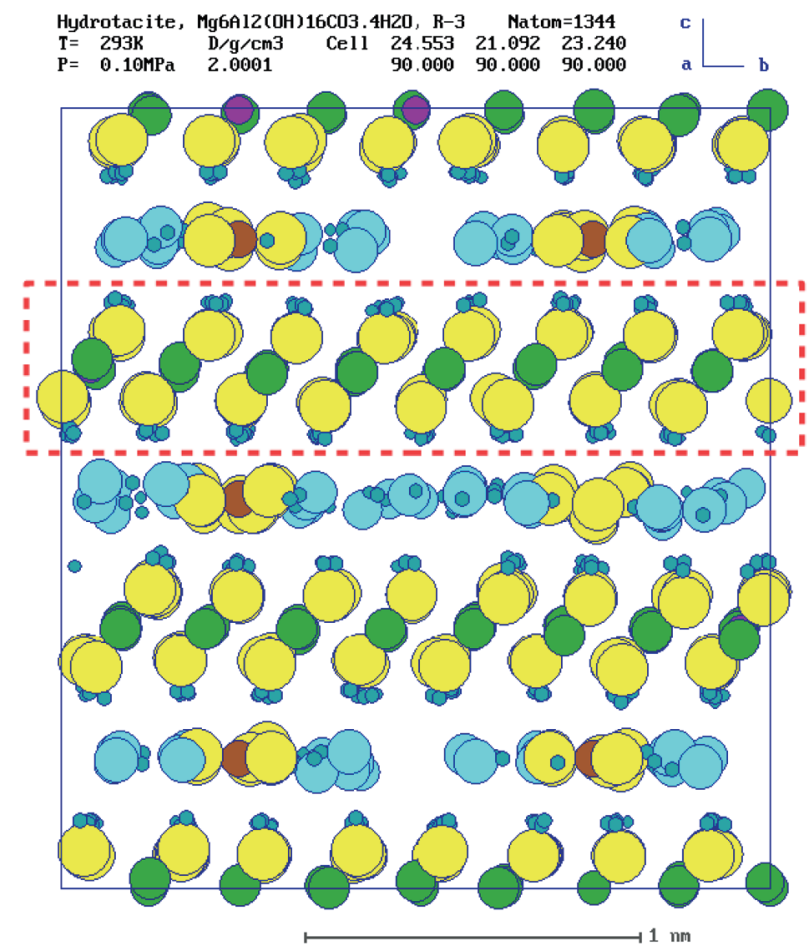

Figure 2. Snapshot of structure of hydrotalcite, $\mathrm{Mg}_{6} \mathrm{Al}_{2}\left[(\mathrm{OH})_{16} \mid \mathrm{CO}_{3}\right] 4 \mathrm{H}_{2} \mathrm{O}$ by $\mathrm{MD}$ simulation. A portion surrounded by dashed line means an octahedral sheet. 
Table 2. Parameters of interatomic potential model for MXDORTO/MXDTRICL

\begin{tabular}{|c|c|c|c|c|c|c|c|}
\hline Hydrotalcite sheet & & & & & & & \\
\hline Atom & $\mathrm{w} / 10^{3} \mathrm{~kg} / \mathrm{mol}^{-1}$ & $\mathrm{z} / \mathrm{e}$ & $\mathrm{a} / \mathrm{nm}$ & $\mathrm{b} / \mathrm{nm}$ & $\mathrm{c} /(\mathrm{kJ} / \mathrm{mol})^{0.5} \mathrm{~nm}^{-3}$ & & \\
\hline $\mathrm{O}$ & 16.00 & -1.19375 & 0.1804 & 0.0151 & 0.05606 & & \\
\hline $\mathrm{Al}$ & 26.98 & 1.950 & 0.0958 & 0.0056 & 0.0 & & \\
\hline $\mathrm{Mg}$ & 24.305 & 1.640 & 0.1049 & 0.0057 & 0.00409 & & \\
\hline $\mathrm{H}$ & 1.01 & 0.460 & 0.0123 & 0.0042 & 0.0 & & \\
\hline $\mathrm{Cl}$ & 35.45 & -1.000 & 0.2200 & 0.0160 & 0.05729 & & \\
\hline I & 126.90 & -1.000 & 0.2350 & 0.0160 & 0.06138 & & \\
\hline Atom-atom & $\mathrm{D}_{1} / \mathrm{kJ} \cdot \mathrm{mol}^{-1}$ & $\beta_{1} / \mathrm{nm}^{-1}$ & $\mathrm{D}_{2} / \mathrm{kJ} \mathrm{mol}^{-1}$ & $\beta_{2} / \mathrm{nm}^{-1}$ & $\mathrm{D}_{3} / \mathrm{kJ} \cdot \mathrm{mol}^{-1}$ & $\beta_{3} / \mathrm{nm}^{-1}$ & $\mathrm{r}_{3} / \mathrm{nm}$ \\
\hline O-Al & 151515.0 & 50.0 & -8145.0 & 22.6 & & & \\
\hline $\mathrm{O}-\mathrm{H}$ & 57394.9 & 74.0 & -2189.3 & 31.30 & 34.74 & 128.0 & 0.1283 \\
\hline Atom-atom-atom & $\mathrm{fk} / 10^{-19} \mathrm{~J}$ & $\theta 0 /{ }^{\circ}$ & $\mathrm{rm} / \mathrm{nm}$ & $\mathrm{gr} / \mathrm{nm}^{-1}$ & & & \\
\hline H-O-H & 1.15 & 99.5 & 0.143 & 92.0 & & & \\
\hline \multicolumn{8}{|l|}{$\mathrm{H}_{2} \mathrm{O}$ molecule } \\
\hline Atom & $\mathrm{w} / 10^{3} \mathrm{~kg} / \mathrm{mol}^{-1}$ & $\mathrm{z} / \mathrm{e}$ & $\mathrm{a} / \mathrm{nm}$ & $\mathrm{b} / \mathrm{nm}$ & $\mathrm{c} /(\mathrm{kJ} / \mathrm{mol})^{0.5} \mathrm{~nm}^{-3}$ & & \\
\hline $\mathrm{O}$ & 16.00 & -0.920 & 0.1728 & 0.01275 & 0.05606 & & \\
\hline $\mathrm{H}$ & 1.01 & 0.460 & 0.0035 & 0.00440 & 0.0 & & \\
\hline Atom-atom & $\mathrm{D}_{1} / \mathrm{kJ} \mathrm{mol}^{-1}$ & $\beta_{1} / \mathrm{nm}^{-1}$ & $\mathrm{D}_{2} / \mathrm{kJ} \mathrm{mol}^{-1}$ & $\beta_{2} / \mathrm{nm}^{-1}$ & $\mathrm{D}_{3} / \mathrm{kJ} \mathrm{mol}^{-1}$ & $\beta_{3} / \mathrm{nm}^{-1}$ & $\mathrm{r}_{3} / \mathrm{nm}$ \\
\hline $\mathrm{O}-\mathrm{H}$ & 57394.9 & 74.0 & -2189.3 & 31.3 & 34.74 & 128.0 & 0.1283 \\
\hline Atom-atom-atom & $\mathrm{fk} / 10^{-19} \mathrm{~J}$ & $\theta 0 /{ }^{\circ}$ & $\mathrm{rm} / \mathrm{nm}$ & $\mathrm{gr} / \mathrm{nm}^{-1}$ & & & \\
\hline H-O-H & 1.15 & 99.5 & 0.143 & 92.0 & & & \\
\hline \multicolumn{8}{|l|}{$\mathrm{CO}_{3}{ }^{2-}$ ion molecule } \\
\hline Atom & $\mathrm{w} / 10^{3} \mathrm{~kg} / \mathrm{mol}^{-1}$ & $\mathrm{z} / \mathrm{e}$ & $\mathrm{a} / \mathrm{nm}$ & $\mathrm{b} / \mathrm{nm}$ & $\mathrm{c} /(\mathrm{kJ} / \mathrm{mol})^{0.5} \mathrm{~nm}^{-3}$ & & \\
\hline $\mathrm{C}$ & 12.01 & 1.240 & 0.0485 & 0.0067 & 0.000 & & \\
\hline $\mathrm{O}$ & 16.00 & -1.080 & 0.1879 & 0.0169 & 0.04501 & & \\
\hline Atom-atom & $\mathrm{D}_{1} / \mathrm{kJ} \cdot \mathrm{mol}^{-1}$ & $\beta_{1} / \mathrm{nm}^{-1}$ & $\mathrm{D}_{2} / \mathrm{kJ} \cdot \mathrm{mol}^{-1}$ & $\beta_{2} / \mathrm{nm}$ & & & \\
\hline $\mathrm{C}-\mathrm{O}$ & 33484.0 & 60.0 & -12138.0 & 24.0 & & & \\
\hline
\end{tabular}

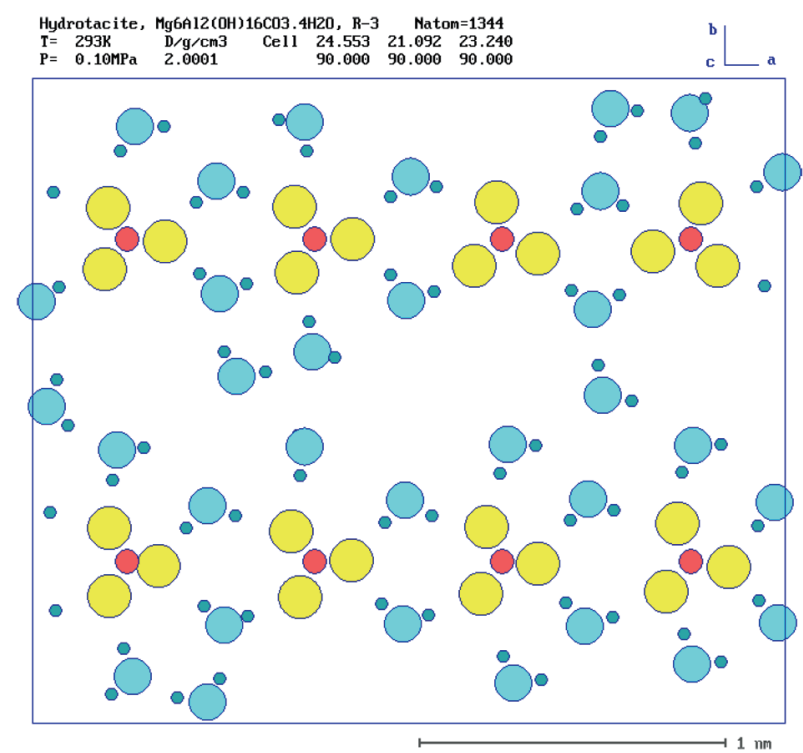

Figure 3. The structure of interlayer $\mathrm{CO}_{3}{ }^{2-}$ and $\mathrm{H}_{2} \mathrm{O}$ from middle layer of Figure 2. structure projected onto the a-b plane is shown in Figure 3. While the $\mathrm{CO}_{3}{ }^{2-}$ units line regularly in the Figure, the arrangement of $\mathrm{H}_{2} \mathrm{O}$ molecules is irregular.

We investigated the cases that relatively small amounts of $\mathrm{H}_{2} \mathrm{O}$ were inserted in interlayer regions of hydrotalcite. $\mathrm{Mg}_{3} \mathrm{Al}$ $(\mathrm{OH})_{8}[\mathrm{Cl}$ or $\mathrm{I}] \cdot \mathrm{nH}_{2} \mathrm{O}$ where $\mathrm{n}=1$ to 20 are investigated by $\mathrm{MD}$ calculations (the structures of $n=1$ to 4 are shown in Figure 4). The structures of these two series are slightly different because of the difference of anion size. In the structure of $\mathrm{n}=2$ and 3 in I-hydrotalcite, the rows of $\mathrm{H}_{2} \mathrm{O}$ molecules are clearly separated in the single interlayer region. Two dimensional diffusion coefficients $\mathrm{D}_{\mathrm{xy}}$ of anions and $\mathrm{H}_{2} \mathrm{O}$ molecules were calculated (Table 4). The diffusion coefficients of $\mathrm{Cl}^{-}$hydrotalcite are smaller than those of I-hydrotalcite. The diffusion coefficient of $\mathrm{H}_{2} \mathrm{O}$ and halide ions in hydrotalcite interlayer is extremly small for $1 \mathrm{H}_{2} \mathrm{O}$ of $\mathrm{Cl}^{-}$hydrotalcite. The diffusion coefficients increase with $\mathrm{n}$ for both anions and $\mathrm{H}_{2} \mathrm{O}$ molecules. In the systems of 
Table 3. The crystal data of hydrotalcite reported by Allmann and Jepsen (1969) [6] and Belloto et al. (1996) [7]. SOF: site occupancy factor, ITF: isometric temperature factor.

\begin{tabular}{|c|c|c|c|c|c|c|}
\hline \multirow{2}{*}{$\frac{\left(\left(\mathrm{Mg}_{4} \mathrm{Al}_{2}\right)(\mathrm{OH})_{\mathbf{1 2}}\left(\mathrm{CO}_{3}\right)\left(\mathrm{H}_{2} \mathrm{O}\right)_{3}\right)_{0.5}}{\text { Trigonal }}$} & \multicolumn{6}{|c|}{ Allmann and Jepsen (1969) } \\
\hline & $\mathrm{R}-3 \mathrm{~m}$ & \multicolumn{3}{|c|}{$\mathrm{a}=3.054, \mathrm{~b}=3.054, \mathrm{c}=22.81,=120^{\circ}$} & \multicolumn{2}{|l|}{$Z=3$} \\
\hline Atom & SITE & $\mathrm{x}$ & $\mathrm{y}$ & $\mathrm{z}$ & \multicolumn{2}{|l|}{ SOF } \\
\hline $\mathrm{Mg}$ & $3 a$ & 0 & 0 & 0 & \multicolumn{2}{|l|}{0.6667} \\
\hline $\mathrm{Al}$ & $3 a$ & 0 & 0 & 0 & \multicolumn{2}{|l|}{0.3333} \\
\hline $\mathrm{O}$ & $6 c$ & 0 & 0 & $0.3771(5)$ & \multicolumn{2}{|l|}{1.} \\
\hline $\mathrm{H}$ & $6 c$ & 0 & 0 & $0.4144(86)$ & \multicolumn{2}{|l|}{1.} \\
\hline $\mathrm{O}$ & $18 \mathrm{~h}$ & $0.092(25)$ & $-0.092(25)$ & 0.5 & \multicolumn{2}{|l|}{0.167} \\
\hline $\mathrm{C}$ & $6 \mathrm{c}$ & 0 & 0 & 0.167 & \multicolumn{2}{|l|}{0.083} \\
\hline \multicolumn{7}{|c|}{$\left(\mathrm{Mg}_{0.833} \mathrm{Al}_{0.167}\right)(\mathrm{OH})_{2}\left(\mathrm{CO}_{3}\right)_{0.083}\left(\mathrm{H}_{2} \mathrm{O}\right)_{0.75}$ Bellotto et al. (1996) } \\
\hline Trigonal & $\mathrm{R}-3 \mathrm{~m}$ & \multicolumn{4}{|c|}{$\mathrm{a}=3.0808(3), \mathrm{b}=3.0808(3), 23.784(4), \gamma=120^{\circ}$} & $\mathrm{Z}=3$ \\
\hline Atom & SITE & $\mathrm{x}$ & $\mathrm{y}$ & $\mathrm{z}$ & SOF & ITF (U) \\
\hline $\mathrm{Mg}$ & $3 \mathrm{a}$ & 0 & 0 & 0 & 0.8333 & $0.0319(8)$ \\
\hline $\mathrm{Al}$ & $3 a$ & 0 & 0 & 0 & 0.1667 & $0.0319(8)$ \\
\hline $\mathrm{O}$ & $6 c$ & 0 & 0 & $0.3754(2)$ & 1. & $0.036(1)$ \\
\hline $\mathrm{H}$ & $6 c$ & 0 & 0 & $0.432(1)$ & 1. & $0.059(7)$ \\
\hline $\mathrm{O}$ & $18 \mathrm{~h}$ & $0.1260(9)$ & $0.8740(9)$ & 0.5 & 0.1667 & $0.021(3)$ \\
\hline $\mathrm{C}$ & $6 c$ & 0.3333 & 0.6667 & 0.5 & 0.0416 & $0.059(7)$ \\
\hline $\mathrm{H}$ & $6 c$ & 0.3333 & 0.6667 & 0.5 & 0.75 & $0.059(7)$ \\
\hline
\end{tabular}

Table 4. Two dimension diffusion coefficients $\mathrm{D}_{\mathrm{xy}}$ of anion and $\mathrm{H}_{2} \mathrm{O}$ molecule in interlayer region of Cl- and I-hydrotalcite at $293 \mathrm{~K}$, $0.1 \mathrm{MPa}$. The $\mathrm{nH}_{2} \mathrm{O}$ means $\mathrm{Mg}_{3} \mathrm{Al}(\mathrm{OH})_{8}[\mathrm{Cl}$ or $\mathrm{I}] \cdot \mathrm{nH}_{2} \mathrm{O}$

\begin{tabular}{cccc}
\hline \multirow{2}{*}{$\mathbf{n H}_{\mathbf{2}} \mathbf{O}$} & \multicolumn{3}{c}{ Diffusion coefficient $\mathbf{D}_{\mathbf{x v}} \mathbf{c} \mathbf{c m}^{\mathbf{2}} / \mathbf{s}$} \\
\cline { 2 - 4 } & \multicolumn{3}{c}{$\mathbf{H}_{\mathbf{2}} \mathbf{O}$} \\
\hline \multirow{2}{*}{$1 \mathrm{H}_{2} \mathrm{O}$} & $\mathrm{Cl}$ & $2.7 \mathrm{E}-7$ & $9.1 \mathrm{E}-7$ \\
& $\mathrm{I}$ & $17.7 \mathrm{E}-7$ & $45.3 \mathrm{E}-7$ \\
$2 \mathrm{H}_{2} \mathrm{O}$ & $\mathrm{Cl}$ & $42.9 \mathrm{E}-7$ & $69.1 \mathrm{E}-7$ \\
& $\mathrm{I}$ & $48.6 \mathrm{E}-7$ & $74.7 \mathrm{E}-7$ \\
$3 \mathrm{H}_{2} \mathrm{O}$ & $\mathrm{Cl}$ & $26.3 \mathrm{E}-7$ & $47.0 \mathrm{E}-7$ \\
& $\mathrm{I}$ & $52.9 \mathrm{E}-7$ & $134.1 \mathrm{E}-7$ \\
$10 \mathrm{H}_{2} \mathrm{O}$ & $\mathrm{Cl}$ & $94.2 \mathrm{E}-7$ & $165.2 \mathrm{E}-7$ \\
& $\mathrm{I}$ & $88.1 \mathrm{E}-7$ & $179.6 \mathrm{E}-7$ \\
$20 \mathrm{H}_{2} \mathrm{O}$ & $\mathrm{Cl}$ & $108.3 \mathrm{E}-7$ & $162.8 \mathrm{E}-7$ \\
& $\mathrm{I}$ & $91.4 \mathrm{E}-7$ & $180.6 \mathrm{E}-7$ \\
\hline
\end{tabular}

$10 \mathrm{H}_{2} \mathrm{O}$ and $20 \mathrm{H}_{2} \mathrm{O}$, the diffusion coefficients of $\mathrm{H}_{2} \mathrm{O}$ molecules are almost the same and the same with bulk water.

\section{Wetting of water on hydrotalcite surface}

Hydrotalcite surface - water systems were investigated by MD simulations to obtain the wetting behavior, the local properties, structure, density, diffusion coefficient, and viscosity of water as functions of distance from hydrotalcite surface.
Wetting of water on the $\mathrm{Cl}^{-}$and I-hydrotalcite surface was investigated using MD calculations. A water drop was positioned initially just in the vicinity of the surface with the whole drop velocity at zero (Figure 5), then MD calculations were started. The water drop is composed of $3000 \mathrm{H}_{2} \mathrm{O}$ molecules and well relaxed previously. The structural snap shots of steady state related structures are displayed in Figure 6. Both $\mathrm{Cl}^{-}$and I-hydrotalcite show very good wetting behavior where wet angles are well less than 30 degrees. In both structures, most of the 


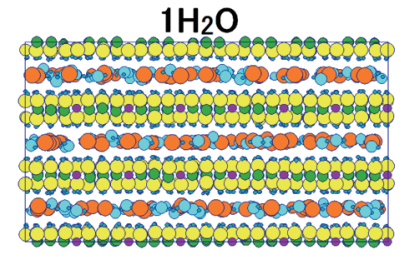

$2 \mathrm{H}_{2} \mathrm{O}$

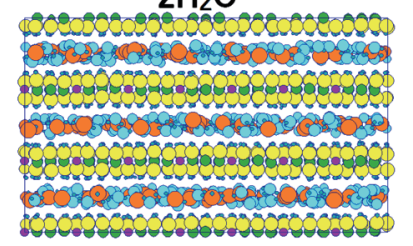

$3 \mathrm{H}_{2} \mathrm{O}$

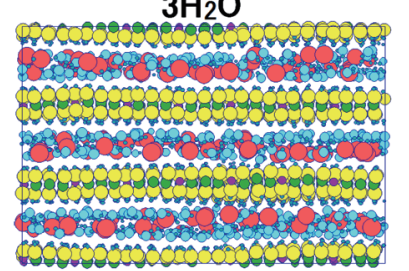

$4 \mathrm{H}_{2} \mathrm{O}$

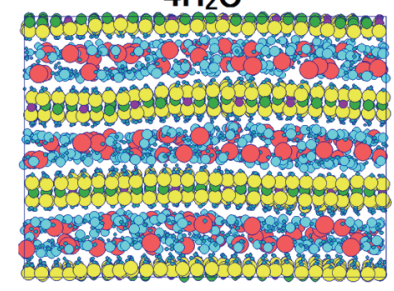

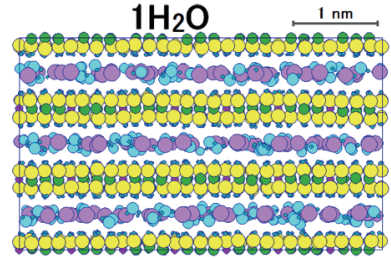

$2 \mathrm{H}_{2} \mathrm{O}$

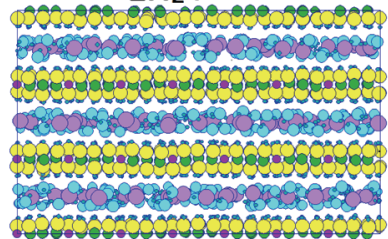

$3 \mathrm{H}_{2} \mathrm{O}$

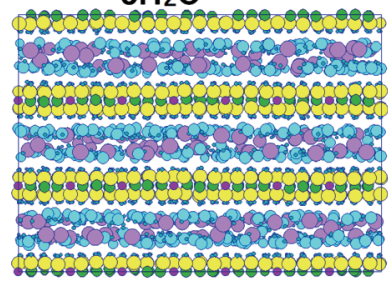

$4 \mathrm{H}_{2} \mathrm{O}$

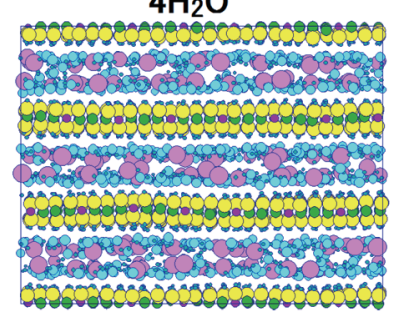

Figure 4. Snapshots of $\mathrm{Mg}_{3} \mathrm{Al}(\mathrm{OH})_{8} \cdot \mathrm{Cl} \cdot \mathrm{nH}_{2} \mathrm{O}$ (left) and $\mathrm{Mg}_{3} \mathrm{Al}$ $(\mathrm{OH})_{8}$. I.nH $\mathrm{nH}_{2} \mathrm{O}$ (right).

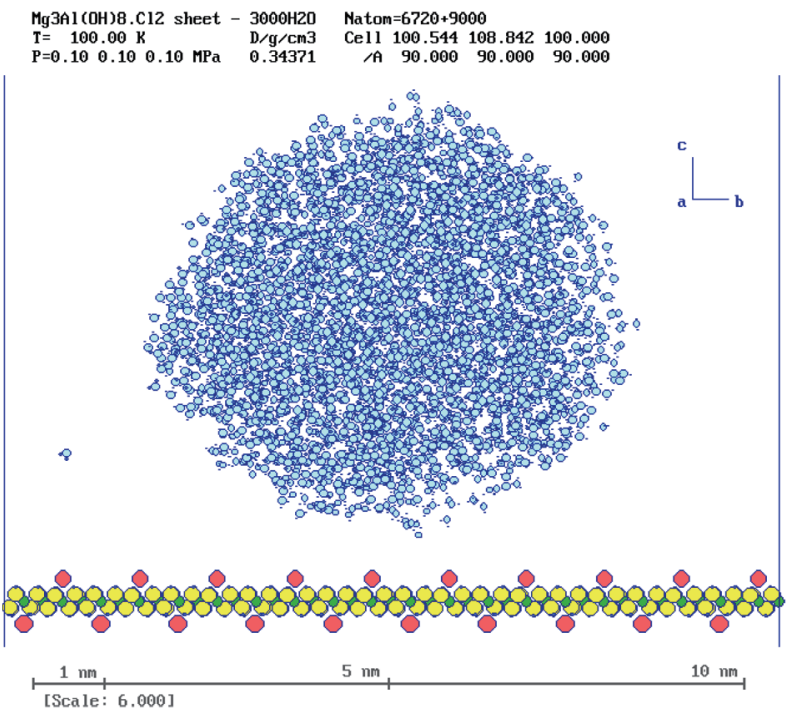

Figure 5. Initial structure of Cl-hydrotalcite surface with A water drop $\left(3000 \mathrm{H}_{2} \mathrm{O}\right.$ molecules $)$ system for MD calculations.
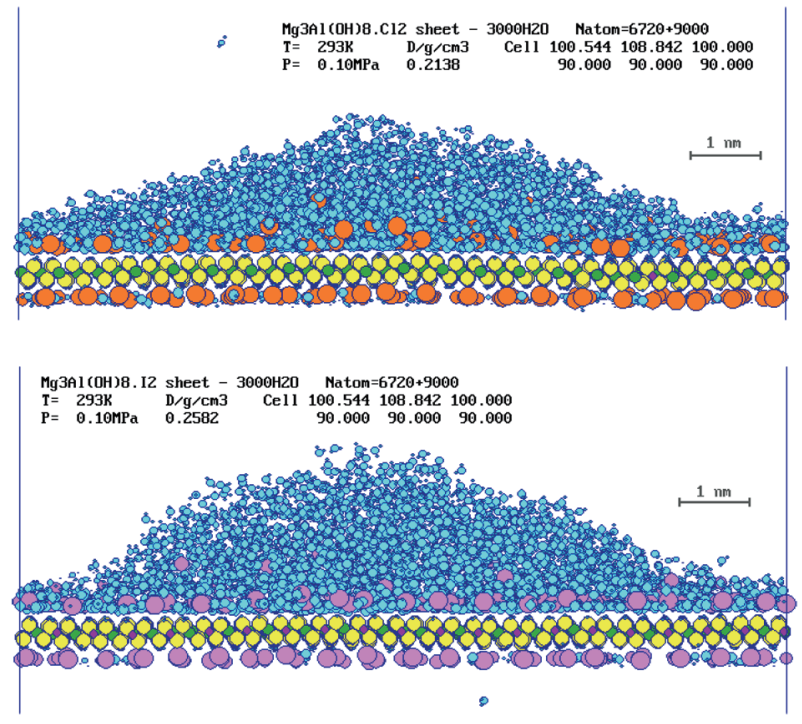

Figure 6. Snapshots of a sheet of Cl-(upper) and I-hydrotalcite (lower) surface - water drop systems, where the number of $\mathrm{H}_{2} \mathrm{O}$ molecules are 3000 for both systems.

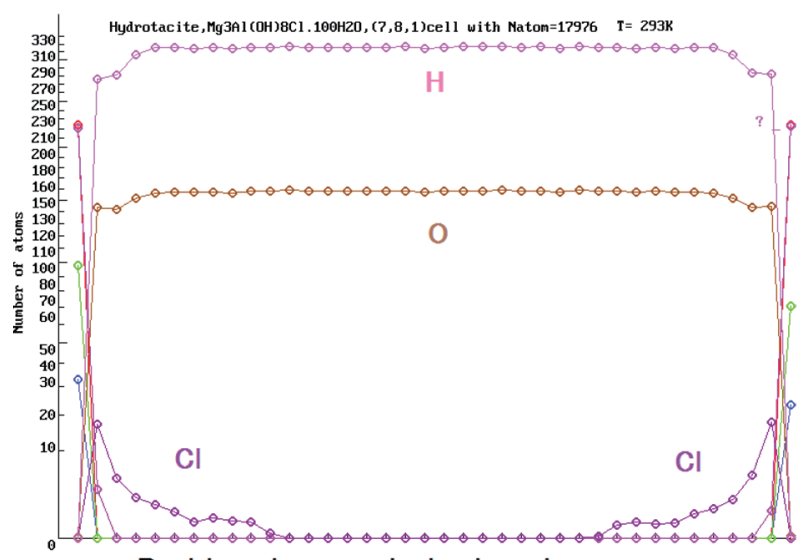

Position along vertical axis to layer structure

Figure 7. Distribution of atoms vertical to Cl-hydrotalcite surface in the hydrotalcite- $200 \mathrm{H}_{2} \mathrm{O}$ system.

anions attach to the hydrotalcite sheet surfaces directly and only a small number of anions are fully hydrated unlike the case of Na-smectite surfaces where the surface has very good wetting properly and the all cations are fully hydrated [10].

\section{Local structure and properties of water between hydrotalcite surfaces}

As the hydrotalcite - intergranular (external or outside interlayer region) water systems, we simulated $\mathrm{Mg}_{6} \mathrm{Al}_{2}(\mathrm{OH})_{16}[\mathrm{Cl}$ or I] $-\mathrm{nH}_{2} \mathrm{O}, \mathrm{n}=40,200$ and 400 systems. The results for 


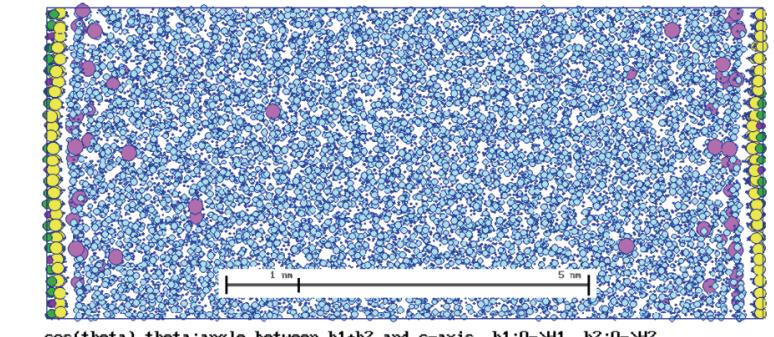

cos(theta) theta:ang le between $\mathrm{h} 1+\mathrm{h} 2$ and $\mathrm{c}-$ axis, $\mathrm{h1}: 0->\mathrm{H1}, \mathrm{h2}: 0->\mathrm{H} 2$

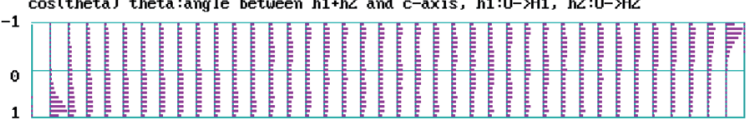

cos(phi) phi :angle between h1Xh2 and c-axis (Div= 2.50A)
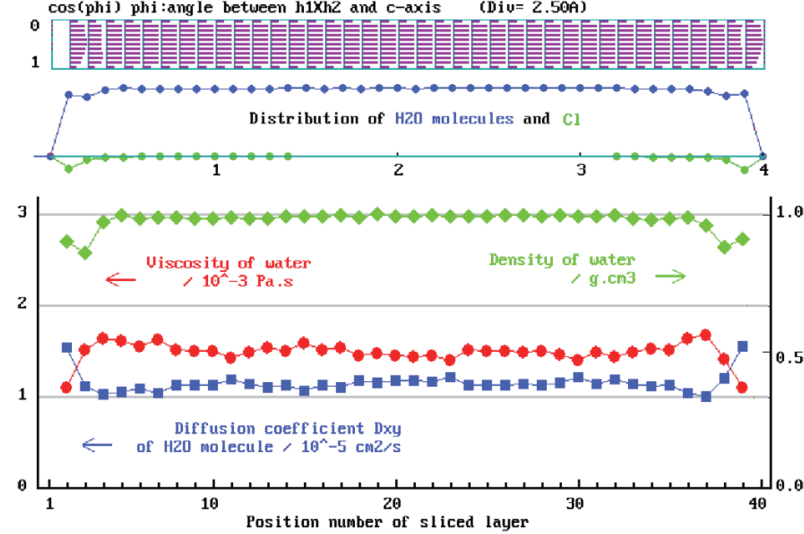

Figure 8. Results of MD calculations of hydrotalcite $\mathrm{Cl}$ $\mathrm{Mg}_{6} \mathrm{Al}_{2}(\mathrm{OH})_{16}-200 \mathrm{H}_{2} \mathrm{O}$ system at $293 \mathrm{~K}$ and $0.1 \mathrm{MPa}$. Structure snapshot (upper), $\mathrm{H}_{2} \mathrm{O}$ molecular orientation statistics and distribution of $\mathrm{H}_{2} \mathrm{O}$ molecules and $\mathrm{Cl}^{-}$ions (middle) where theta means angles between dipoles of $\mathrm{H}_{2} \mathrm{O}$ molecules and c-axis and phi means angles between the normal vector of $\mathrm{H}_{2} \mathrm{O}$ molecular plane and c-axis, and diffusion coefficient of $\mathrm{H}_{2} \mathrm{O}(\square)$, viscosity of water (๑), and distribution of $\mathrm{H}_{2} \mathrm{O}$ molecules ( ) (bottom). The vertical axis is shown in the left side of the Figure with the units of $1 \times 10^{-5} \mathrm{~cm} / \mathrm{s}$ for diffusion coefficient and $1 \times 10^{-3}$ for viscosity respectively.

$\mathrm{Mg}_{6} \mathrm{Al}_{2}(\mathrm{OH})_{16}[\mathrm{Cl} \text { or }]_{2}-200 \mathrm{H}_{2} \mathrm{O}$ system are shown in Figures 7 and 8 . Local structure and properties were calculated every $0.25 \mathrm{~nm}$ thick layer of the water parallel to the hydrotalcite surface whose thickness is nearly equal to the diameter of an $\mathrm{H}_{2} \mathrm{O}$ molecule. The atom distributions perpendicular to hydrotalcite surface are displayed in Figure 7. $\mathrm{Cl}^{-}$ions distribute only near the mineral layer surfaces. The orientations of $\mathrm{H}_{2} \mathrm{O}$ molecular dipoles are strongly biased at the interfaces and the directions are clearly from the mineral layer surface to inside water (Figure 8, middle). The electrical double layer was formed as the Stern layer of one molecular layer of surface water where the molecular orientations are strongly biased and the diffusion

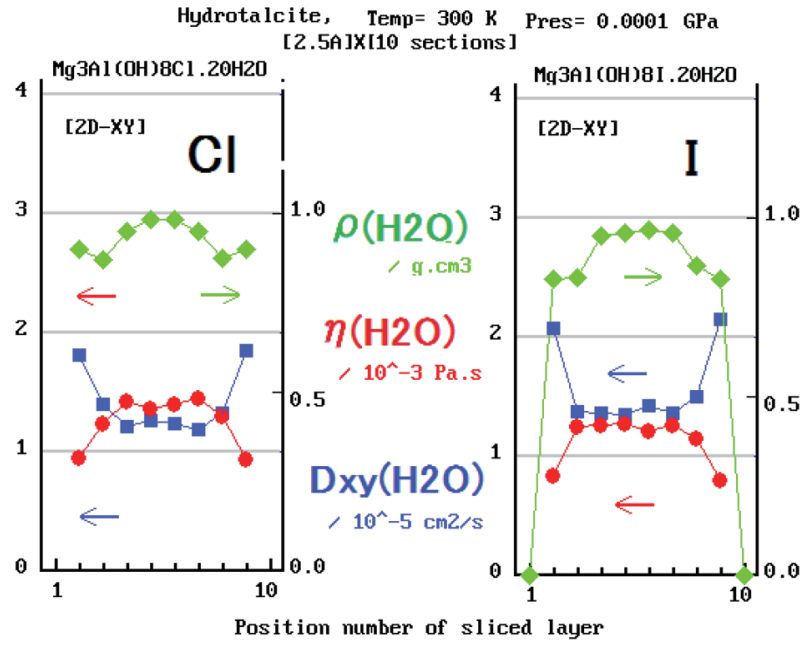

Figure 9. Diffusion coefficient of $\mathrm{H}_{2} \mathrm{O}(\square)$, viscosity (๑), and density of $\mathrm{H}_{2} \mathrm{O}(>)$ of hydorotalcite, $\mathrm{X}-\mathrm{Mg}_{6} \mathrm{Al}_{2}(\mathrm{OH})_{16}-40 \mathrm{H}_{2} \mathrm{O}$ $(\mathrm{X}=\mathrm{Cl}($ left $)$ and $\mathrm{I}($ right $)$ ) systems.

layer of about $2.5 \mathrm{~nm}$ thickness where $\mathrm{Cl}^{-}$ion distribute there (Figure 7). The I-hydrotalcite shows the same structure in our calculations. The density profile of water shows the decrease at the surface two molecular layers of water unlike the case of Nasmectite [8]. Diffusion coefficients of water show the maxima at the surfaces, and decrease with distance from the surfaces to three $\mathrm{H}_{2} \mathrm{O}$ molecule distance, and increase slightly again with distance in the region where $\mathrm{Cl}^{-}$ions exist. The viscosity shows the reverse behavior to that of diffusion coefficient. This behavior was reported for brucite surface $\left(\mathrm{Mg}(\mathrm{OH})_{2}\right)$ by Sakuma et al. [11]. It is, however, more prominent for hydrotalcite surface than for brucite surface. The diffusion coefficient of $\mathrm{H}_{2} \mathrm{O}$ is larger in $\mathrm{Cl}^{-}$hydrotalcite than in I-hydrotalcite and the viscosity of external (pore) water of $\mathrm{Cl}^{-}$hydrotalcite is smaller than that of I-talcite as shown in Figure 9. This can be explained by the difference of ionic radii of halide ions. Namely, the large anion $\mathrm{I}^{-}$has weaker interaction between halide ion and $\mathrm{H}_{2} \mathrm{O}$ molecule than $\mathrm{Cl}^{-}$ion

\section{Conclusions}

The crystal structure of hydrotalcite was reasonably modeled and reproduced using molecular dynamics simulations with the appropriate interatomic potential model of hydrotalcite sheet, $\mathrm{H}_{2} \mathrm{O}$ molecule, halide anions, and $\mathrm{CO}_{3}{ }^{2-}$ ion. Wetting of water drop on hydrotalcite surfaces show fairly good wetting behav- 
ior with wetting angle well less than 30 degrees. We performed hydrotalcite - intergranular (pore) water systems, and calculated local density, diffusion coefficients, and viscosity of water. The behavior of hydrotalcite surface - external water resembles that of brucite surface. But wetting property of hydrotalcite is much better than that of brucite. The decrease of the viscosity of water at the interface between mineral suface and pore water is more prominent in hydrotalcite than in brucite.

\section{References}

[1] H. Struntz, E. H. Nickel, "Struntz Mineralogical Tables. Chemical-Structural Mineral Classification System", $9^{\text {th }}$ ed. Stuttgart, Schweizerbart (2001)

[2] J. Wang, A. G. Kalinchev, R. J. Kirkpatrick, X. Hou, Chem. Mater., 13, 145 (2001). [CrossRef]
[3] J. Wang, A. G. Kalinichev, J. E. Amonette, R. J. Kirkpatrick, Am. Mineral., 88, 398 (2003). [CrossRef]

[4] K. Hirao, K. Kawamura, "Material Design using Personal Computers" (Japanese), Shokabou, 217p. (1994)

[5] Kumagai, N., Kawamura, K. and Yokokawa, T., 12, pp. 177- 186 (1994).

[6] M. Nakano, K. Kawamura, Y. Ichikawa, Appl. Clay Sci., 23, 15 (2003). [CrossRef]

[7] K. Kawamura, Low Temp. Sci., 65, 3 (2005).

[8] Allmann, R., Jepsen, H.P, . Neues Jahrbuch fuer Mineralogie. Monatshefte (Band=Jahr), 544-551 (1969)

[9] M. Bellotto, B. Rebours, O. Clause, J. Lynch, D. Bazin, E. Elkaim, J. Phys. Chem., 100, 8527 (1996). [CrossRef]

[10] K. Kawamura, Chikyuukagaku, 42, 115 (2008).

[11] H. Sakuma, T. Tsuchiya, K. Kawamura, K. Otsuki, Surf. Sci., 536, L396 (2003). [CrossRef] 